\title{
Study of $\mathrm{BaTiO}_{3}$ ceramics doped with $\mathrm{Mn}$ and $\mathrm{Ce}$ or $\mathrm{Nb}$ and $\mathrm{Sr}$
}

\author{
A.M.Slipenyuk, M.D.Glinchuk, I.P.Bykov, L.P.Yurchenko, \\ V.A.Mikheev, O.A.Frenkel, V.D.Tkachenko, E.P.Garmash \\ Institute for Problems of Materials Science \\ of the National Academy of Sciences of Ukraine, \\ 3 Krjijanovskogo Str., 03680 Kiev-142, Ukraine
}

Received December 12, 2002, in final form April 8, 2003

\begin{abstract}
ESR study of $\mathrm{BaTiO}_{3}$ ferroelectrics doped with cerium or with niobium and strontium, both types of samples being doped with manganese, was performed at room temperature. In the samples of the first type the most intensive line with $g$-factor 1.9612 was shown to originate from paramagnetic center $\mathrm{Ti}^{3+}-\mathrm{Ce}^{3+}$. The small intensity line was related to $\mathrm{Fe}^{3+}-\mathrm{V}_{\mathrm{O}}$ center, which can be unavoidable impurity in $\mathrm{BaTiO}_{3}$.

In the samples doped with strontium, the six lines intensive spectrum, which corresponds to hyperfine structure of $\mathrm{Mn}^{2+}$, was observed. The intensity of the spectrum was shown to decrease with strontium concentration increase. This effect was supposed to be related to the decrease of the grain sizes that results in migration of manganese and, possibly, niobium ions. The influence of these impurities, of their charge states and positions in crystalline lattice of $\mathrm{BaTiO}_{3}$ on the PTCR effect is discussed.
\end{abstract}

Key words: $\mathrm{BaTiO}_{3}$ ceramics, impurities, positive temperature coefficient of resistivity

PACS: $72.80 . S k, 76.30 . F C, 77.84 . D y$

\section{Introduction}

The positive temperature coefficient of resistivity (PTCR) effect in $\mathrm{BaTiO}_{3}$ ceramics is widely regarded as a grain boundary-controlled phenomenon [1,2]. In spite of numerous studies of the factors influencing the PTCR effect, it is still poorly characterized and technological advances in optimizing the PTCR profile have taken place ahead of a better understanding of the underlying scientific phenomenon. Various theories $[1,3-5]$ of the PTCR effect have been proposed. One of the most important problem which is still unsolved is the influence of the impurities on this effect. This problem was studied by several authors [6-8] to clear up the states of the impurities in $\mathrm{BaTiO}_{3}$ ceramics and their influence on the materials' properties. It was shown (see e.g. $[9,10]$ ) that PTCR effect in $\mathrm{BaTiO}_{3}$ ceramics, doped with

(C) A.M.Slipenyuk, M.D.Glinchuk, I.P.Bykov, L.P.Yurchenko, V.A.Mikheev, O.A.Frenkel, 237 V.D.Tkachenko, E.P.Garmash 
donors (e.g. rare-earth ions or $\mathrm{Nb}^{5+}$ ions) can be significantly increased by adding small amounts of $3 \mathrm{~d}$-ions, the most effective among them being $\mathrm{Cu}^{2+}$ or $\mathrm{Mn}^{2+}$. This additional doping leads to an increase of $\rho_{\max } / \rho_{\min }$ ratio ( $\rho$ is electric resistivity) which is the most important feature to be applied. On the other hand, the dopants are known to influence the temperature of the ferroelectric phase transition $\left(T_{\mathrm{c}}\right)$, e.g. lead and zirconium additives shift $T_{\mathrm{c}}$ to the range of larger and smaller temperatures, respectively. From technological point of view, it is worth mentioning that the impurities influence the kinetics of the ceramics sintering since the diffusion processes depend on the defects and the impurities in the lattices. Therefore, the investigations of the type of the defects and of the impurities, their charge state and position in the lattice play a decisive role in understanding the nature of the PTCR effect and in optimizing $\mathrm{BaTiO}_{3}$ ceramics properties.

The main goal of this work was the investigation of $\mathrm{BaTiO}_{3}$ ceramics doped by several impurities ( $\mathrm{Ce}$ and $\mathrm{Mn}$ or $\mathrm{Nb}, \mathrm{Sr}$ and $\mathrm{Mn}$ ) by measurements of the ESR spectra and temperature dependence of electroresistivity. The X-ray and electronmicroscopy analysis were also used.

\section{Experimental details}

The samples of posistor ceramics of $\mathrm{BaTiO}_{3}$ were fabricated from $\mathrm{BaCO}_{3}$ and $\mathrm{TiO}_{2}$ of high purity. The doping was made by addition of $\mathrm{SrCO}_{3}, \mathrm{Nb}_{2} \mathrm{O}_{5}$ and $\mathrm{MnCl}_{2}$. The synthesis was performed by conventional technology at $T=1380{ }^{\circ} \mathrm{C}$ during one hour. The ceramic samples were pellets with sizes: $D=12 \mathrm{~mm}, h=2 \mathrm{~mm}$. The phase content of the ceramics was controlled by X-ray diffraction method. The electric resistivity $\rho$ of the investigated samples was measured by a four-point method. The layers of In and pure graphite were used as electrodes with the surface resistivity smaller than $0.5 \Omega \mathrm{m} / \mathrm{cm}^{2}$.

ESR spectra were recorded at $9.4 \mathrm{GHz}$ spectrometer at room temperature. The measurements were carried out on the powders of the studied samples.

\section{The results of measurements}

1. X-ray diffraction investigations of $\mathrm{BaTiO}_{3}$ samples doped with $\mathrm{Sr}, \mathrm{Ce}, \mathrm{Nb}$ and $\mathrm{Mn}$ were carried out. The decrease of peaks 422 and 244 splitting at $\mathrm{Sr}$ concentration $x>0.35$ along with asymmetrical peak broadening may be the consequence of coexistence of cubic and tetragonal phases in the ceramics. These results are similar to those obtained in previous works (see for instance $[6,7,10]$.

2. The ESR spectra observed in the $\mathrm{BaTiO}_{3}$ ceramics doped with cerium and with cerium and manganese are depicted in figure $1 \mathrm{a}$ and $1 \mathrm{~b}$, respectively. The most intensive line in figure 1a has $g$-factor 1.9612. This line was observed earlier in several works, but its nature is still under discussion. In particular, it was recently shown that the line with $g=1.961$ can be related to paramagnetic 


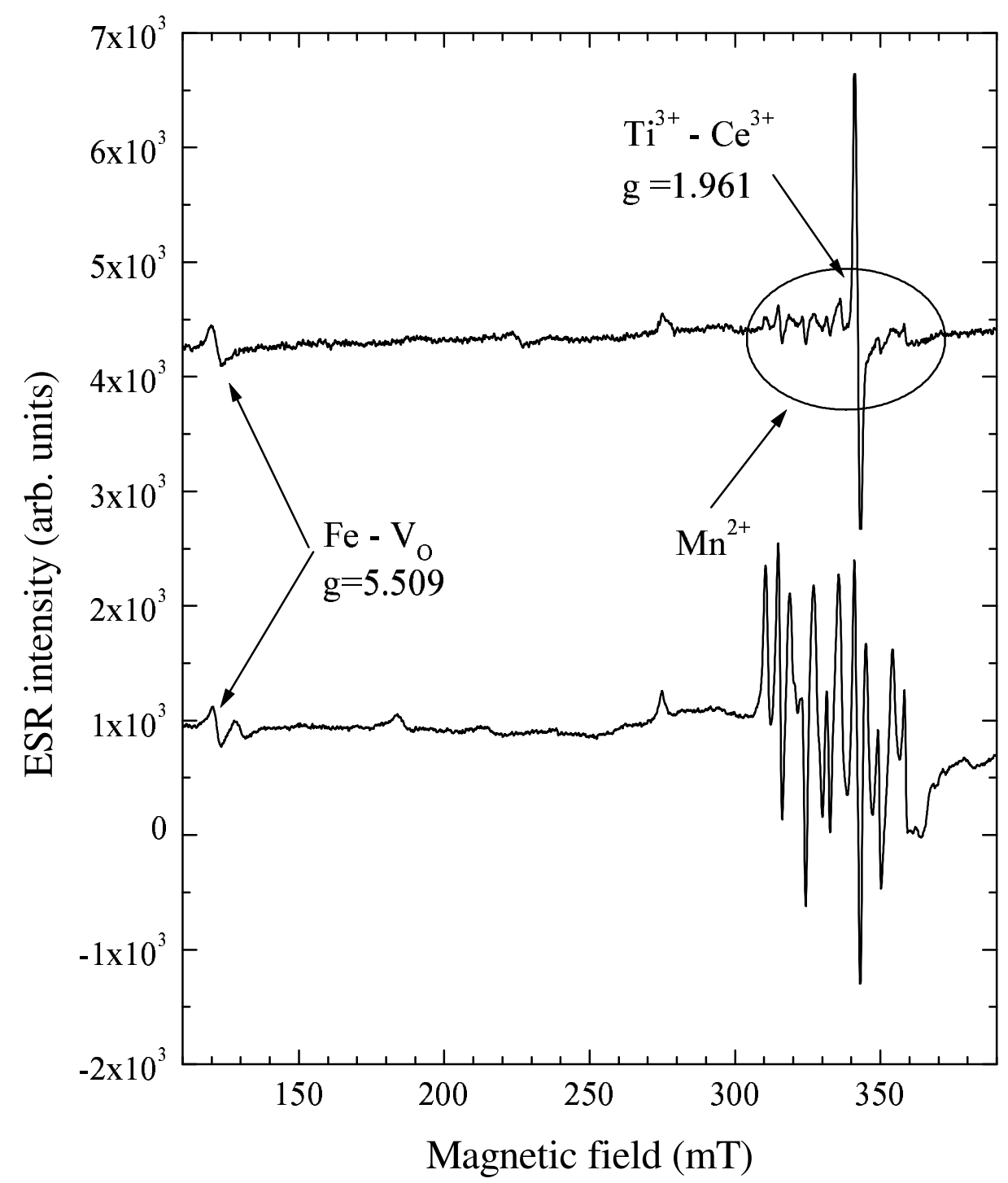

Figure 1. ESR spectra in $\mathrm{BaTiO}_{3}$ ceramics doped with $\mathrm{Ce}_{2} \mathrm{O}_{3}$ (a), $\mathrm{MnO}$ and $\mathrm{Ce}_{2} \mathrm{O}_{3}(\mathrm{~b})$.

complex $\mathrm{Ti}^{3+}-\mathrm{Ln}^{3+}\left(\mathrm{Ln}^{3+}\right.$ is a rare-earth ion) [11], while in [12] it was supposed that it belongs to $\mathrm{Ti}^{3+}-\mathrm{V}_{\mathrm{O}}$. Another line in the spectrum has $g$-factor 5.549. The line with practically the same $g$-factor was observed earlier in the ceramic samples of $\mathrm{BaTiO}_{3}$ doped with rare-earth ions (Y, La, Sm, Dy) [13]. This line was identified as that from paramagnetic center $\mathrm{Fe}^{3+}-\mathrm{V}_{\mathrm{O}}$ where iron ions were unavoidable impurities. The intensity of the line with $g \approx 1.9612$ slightly decreased while the line with $g=5.549$ practically conserves its parameters.

The small intensive lines in the vicinity of $g \approx 2$ observed in Ce-doped $\mathrm{BaTiO}_{3}$ may be related to unavoidable impurity of manganese, which is often present in $\mathrm{BaTiO}_{3}$ ceramics. The confirmation of this supposition was obtained from the measurements of the $\mathrm{BaTiO}_{3}$ samples doped both with $\mathrm{Ce}$ and $\mathrm{Mn}$ (see figure $1 \mathrm{~b}$ ), where the intensity of the ESR lines near $g \approx 2$ strongly increased. 


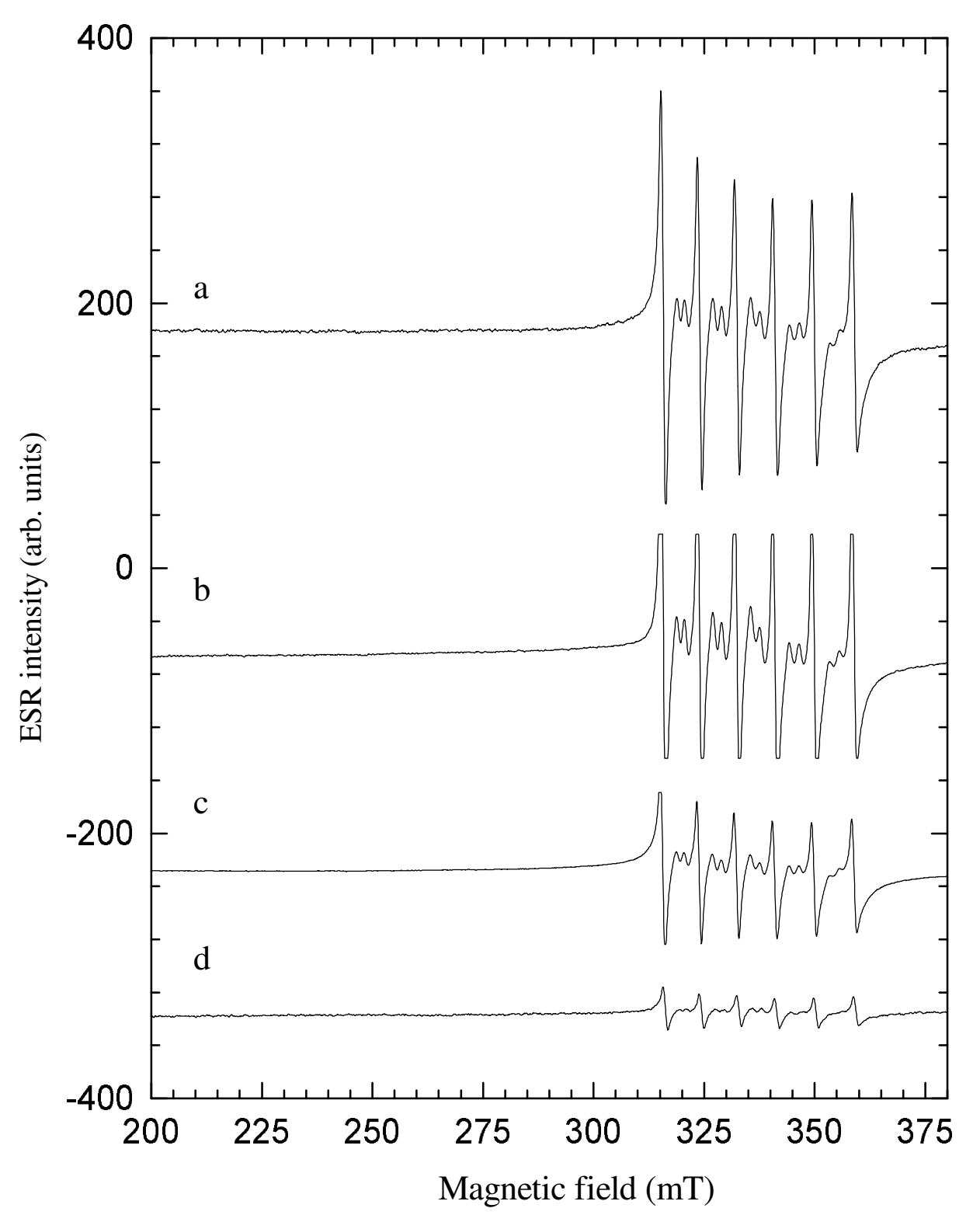

Figure 2. ESR spectra of $\mathrm{Mn}^{2+}$ in $\mathrm{Ba}_{1-x} \mathrm{Sr}_{x} \mathrm{TiO}_{3}$ ceramics doped with $\mathrm{MnO}$ and $\mathrm{Nb}_{2} \mathrm{O}_{5}$ : (a) $x=0.2$, (b) $x=0.3$, (c) $x=0.35$, (d) $x=0.4$.

The characteristic hyperfine structure of the spectra speaks in favor of the statement that this spectrum belongs to $\mathrm{Mn}^{2+}$ ions.

The spectrum of the $\mathrm{Mn}^{2+}$ with six hyperfine lines was clearly observed in the $\mathrm{BaTiO}_{3}$ samples doped with $\mathrm{Sr}, \mathrm{Nb}$ and $\mathrm{Mn}$ ions (see figure 2). One can see that the intensity of the $\mathrm{Mn}^{2+}$ spectrum decreases with the increase of strontium concentration. The dependence of $\mathrm{Mn}^{2+}$ spectrum intensity on $\mathrm{Sr}$ concentration is depicted in figure 3 . Note that we did not observe the spectrum of the $\mathrm{Fe}^{3+}-\mathrm{V}_{\mathrm{O}}$ in these samples. 


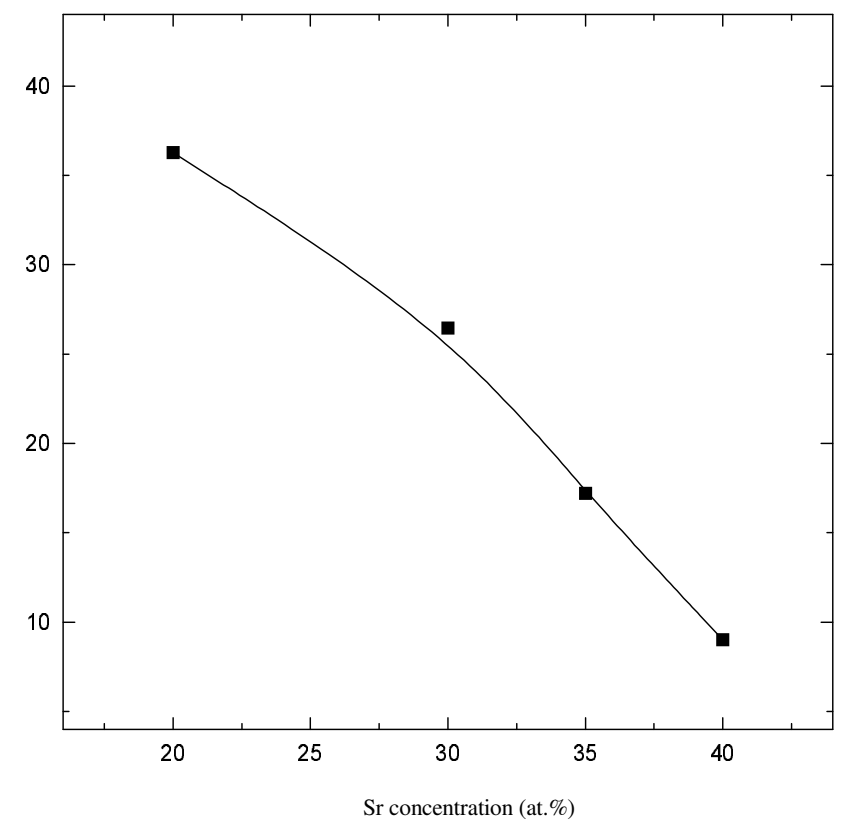

Figure 3. Dependence of $\mathrm{Mn}^{2+}$ ESR spectra intensity in $\mathrm{Ba}_{1-x} \mathrm{Sr}_{x} \mathrm{TiO}_{3}$ doped with $\mathrm{MnO}$ and $\mathrm{Nb}_{2} \mathrm{O}_{5}$ on strontium concentration.

3. The temperature dependence of the resistivity of $\mathrm{Ba}_{1-x} \mathrm{Sr}_{x} \mathrm{TiO}_{3}$ samples doped with 0.3 at. $\%$ of $\mathrm{Nb}$ and 0.1 at. $\%$ of $\mathrm{Mn}$ is depicted in figure 4 . One can see that at room temperature the resistivity of all the samples is low and it slightly changes from $2.5 \mathrm{k} \Omega \mathrm{m}$ to $9.8 \mathrm{k} \Omega \mathrm{m}$. The temperature of the ferroelectric/paraelectric phase transition depends on Sr content. In particular, at $x=0.4 T_{\mathrm{c}}$ shifts at more than 60 degrees. Therefore, Sr-doped $\mathrm{BaTiO}_{3}$ samples show the PTCR effect close to a room temperature.

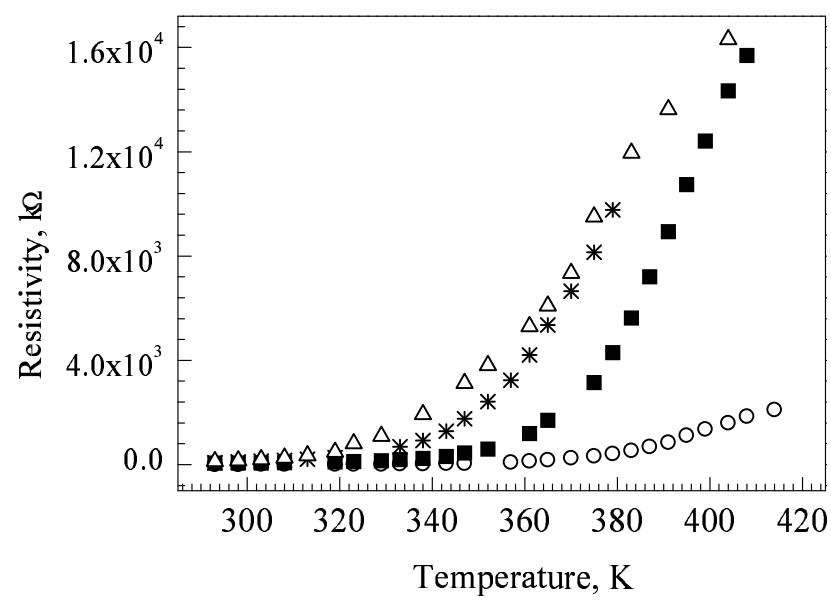

Figure 4. Temperature dependence of resistivity of barium titanate ceramic samples with different strontium content $x: \circ-0.2, \mathbf{\square}-0.3, *-0.35, \triangle-0.4$. 


\section{Discussion}

The most probable $\mathrm{Ce}^{3+}$ ions are substitute for $\mathrm{Ba}^{2+}$, because the ionic radius of $\mathrm{Ce}^{3+}(r=1.034 \AA)$ is much larger than that of $\mathrm{Ti}^{4+}(r=0.68 \AA)$. For the sake of excess positive charge compensation the $\mathrm{Ti}^{3+}-\mathrm{Ce}^{3+}$ center can appear. Since $\mathrm{Ti}^{3+}$ is a paramagnetic ion with spin $S=1 / 2$, the ESR line of Ti related center will arise. We observed similar spectra in $\mathrm{BaTiO}_{3}$ ceramics doped by rare-earth ions [11]. Since the correlation between ESR spectra intensity and rare-earth ions concentration was revealed, the spectra were ascribed to $\mathrm{Ti}^{3+}-\mathrm{Ln}^{3+}$ centers, where $\mathrm{Ln}^{3+}$ is a rare-earth ion. Moreover, there was shown a correlation of these centers ESR-line intensity and the conductivity behaviour. Namely, the ESR spectra intensity increase corresponds to the increase of conductivity and vise versa. These facts made it possible to suppose that the ESR line with $g=1.9612$ belongs to $\mathrm{Ti}^{3+}-\mathrm{Ce}^{3+}$ related centers and namely they lead to semiconductor properties of $\mathrm{BaTiO}_{3}$.

In the $\mathrm{Nb}$-doped $\mathrm{BaTiO}_{3}$ samples, the situation differs from the case considered above. The $\mathrm{Nb}^{5+}$ ionic radius $(0.69 \AA)$ is much smaller than that of $\mathrm{Ce}^{3+}$ and close to ionic radius of $\mathrm{Ti}^{4+}$. Therefore, $\mathrm{Nb}^{5+}$ substitutes $\mathrm{Ti}^{4+}$ in the lattice producing excessive positive charge. For an excessive charge compensation the $\mathrm{Ti}^{3+}-\mathrm{Nb}^{5+}$ centers can arise. However, due to an intensive $\mathrm{Mn}^{2+}$ spectrum it appeared impossible to observe the ESR line of these centers. On the other hand, for an excessive positive charge compensation, the $\mathrm{Nb}^{5+}-\mathrm{Mn}^{3+}$ centers can also arise. Unfortunately, $\mathrm{Mn}^{3+}$ is ESR silent, so it appeared impossible to check this supposition. Usually only the spectra of $\mathrm{Mn}^{2+}(S=5 / 2)$ and $\mathrm{Mn}^{4+}(S=3 / 2)$ can be observed.

In pure $\mathrm{BaTiO}_{3}$ ceramics it appeared possible to observe the $\mathrm{Mn}^{2+}$ spectrum in low temperature ferroelectric phases (orthorhombic and rhombohedral) or in paraelectric phase $\left(T>T_{\mathrm{c}}\right)$. To observe it at room temperature (tetragonal phase), the doping of $\mathrm{BaTiO}_{3}$ is necessary to make a lattice distortion and to change a local symmetry. Such $\mathrm{Mn}^{2+}$ spectrum was observed earlier at room temperature in Laand Mn-doped $\mathrm{BaTiO}_{3}$ samples [14], and the spectra were described by $g_{\|}=2.028$ and $g_{\perp}=2.0024$. Above $T_{\mathrm{c}}$ only one spectrum with larger intensity was recorded. In our measurements of Nb-, Sr-, Ce- and Mn-doped $\mathrm{BaTiO}_{3}$ ceramics $\mathrm{Mn}^{2+}$ ESR spectra were observed at room temperature. The strong decrease of $\mathrm{Mn}^{2+} \mathrm{ESR}$ intensity with the increase of Sr concentration can be related to the decrease of the grain size as the electron microscopy has shown. Since the spectra that we observed originate from $\mathrm{Mn}^{2+}$ ions in the grains and the decrease of grain sizes causes a decrease of ESR intensity. The dependence of the charge state of impurity ions on their position in the grain or intergrain space was observed earlier in PZT ceramics [15-17].

The measurements of the electric resistivity had shown that at room temperature the resistivity increases by an order of magnitude with the increase of Sr concentration. The temperature of PTCR effect strongly depends on Sr content and, at $x=0.4$, a resistivity jump occurs at $60{ }^{\circ} \mathrm{C}$ which is very important for application in the modern technologies.

In conclusion we want to underline that this is part of a larger study to investigate the mechanisms behind the positive temperature coefficient of resistivity 
observed in the doped $\mathrm{BaTiO}_{3}$ ceramics (see $[11,13,18,19]$ ). In the present work, we studied the $\mathrm{Sr}, \mathrm{Ce}, \mathrm{Nb}$ and $\mathrm{Mn}$ influence on the $\mathrm{BaTiO}_{3}$ properties. Both $\mathrm{Nb}$ and Ce ions provide the semiconductor properties of the $\mathrm{BaTiO}_{3}$ ceramics, and the $\mathrm{Mn}$ ions create the centers which are the traps of charge carriers. $\mathrm{SrTiO}_{3}$ is an incipient ferroelectric with $T_{\mathrm{C}}\left(\mathrm{SrTiO}_{3}\right) \ll T_{\mathrm{C}}\left(\mathrm{BaTiO}_{3}\right)$. Therefore, the $\mathrm{BaTiO}_{3}$ doping with strontium titanate leads to $T_{\mathrm{C}}$ shift to the low temperature range. In this work, on the basis of our previous studies, there was theoretically predicted the type and concentrations of dopants in $\mathrm{BaTiO}_{3}$ ceramics, which provide the PTCR effect at room temperature. Corresponding samples were manufactured and there was experimentally confirmed the existence of the effect of positive temperature coefficient of resistivity at temperatures close to a room temperature under strontium content over 35 at.\% and $\mathrm{Ce}, \mathrm{Nb}$ and $\mathrm{Mn}$ concentration $0.1-0.3$ at.\%.

It is obvious that the doping of $\mathrm{BaTiO}_{3}$ ceramics with several impurities can be useful in managing the value of PTCR effect as well as the temperature range of the occurrence of this effect.

\section{Acknowledgements}

Authors are acknowledged to Dr. G.S.Oleynik for electron-microscopy analysis of the samples.

\section{References}

1. Heywang W. // J. Am. Ceram. Soc., 1964, vol. 47, p. 484-493.

2. Goodman G. // J. Am. Ceram. Soc., 1963, vol. 46, p. 45-49.

3. Jonker G.H. // Solid State Electron., 1964, vol. 7, p. 895-899.

4. Jonker G.H. // Mater. Res. Bull., 1969, vol. 2, p. 401-405.

5. Daniels J., Haerdtl K.H., Wernicke R. // Philips. Tech. Rev., 1977, vol. 38, p. 73-79.

6. Ueoka H. // Ferroelectrics, 1974, vol. 7, p. 351-356.

7. Ikushima H., Hayakawa S. // Natl. Tech. Rept., 1967, vol. 13, p. 209-216.

8. Matsuoka T., Fujimura M., Matsuo Y., Hayakawa S. // J. Am. Ceram. Soc., 1972, vol. 55 , p. $108-116$.

9. Matsuoka T., Fujimura M., Matsuo Y., Hayakawa S. // Natl. Tech. Rept., 1975, vol. 21, p. 329-339.

10. Jida S., Miki T. // J. Appl. Phys., 1996, vol. 80, p. 5234-5245.

11. Glinchuk M.D., Bykov I.P., Kornienko S.M., Laguta V.V., Slipenyuk A.M. et al. // Journal of Materials Chemistry, 2000, vol. 10, p. 941-948.

12. Kutty T.R.N., Muragaraj P., Gajbhiye N.S. // Mater. Lett., 1984, vol. 2, p. 396-399.

13. Kornienko S.M., Bykov I.P., Glinchuk M.D., Laguta V.V., Belous A.G., Jastrabik L. // FTT, 1999, vol. 41, p. 1838-1842 (in Russian).

14. Kutty T.R.N., Muragaraj P. // Mater. Lett., 1985, vol. 3, p. 195-198.

15. Bykov I.P., Glinchuk M.D., Skorokhod V.V. // FTT, 1992, vol. 34, p. 1353-1358 (in Russian).

16. Boudys M., Mejezchleb K. // Ferroelectrics, 1992, vol. 126, p. 247-254. 
17. Glinchuk M.D., Bykov I.P., Skorokhod V.V., Kala T. // Ferroelectrics, 1992, vol. 131, p. 223-227.

18. Slipenyuk A.M., Glinchuk M.D., Bykov I.P., Laguta V.V., Bilous A.G., V'yunov O.I. // Ferroelectrics, 2001, vol. 254, p. 349-357.

19. Slipenyuk A.M., Glinchuk M.D., Laguta V.V., Bykov I.P., Bilous A.G., V'yunov O.I. // Ferroelectrics, 2001, vol. 254, p. 383-391.

\title{
Дослідження кераміки $\mathrm{BaTiO}_{3}$ легованої Mn та Сe або $\mathrm{Nb}$ та $\mathrm{Sr}$
}

\author{
А.М.Сліпенюк, М.Д.Глинчук, І.П.Биков, Л.П.Юрченко, \\ В.А.Міхеєв, О.А.Френкель, В.Д.Ткаченко, Є.П.Гармаш \\ Інститут проблем матеріалознавства НАН України, \\ 03680 Київ-142, вул. Кржижановського, 3
}

Отримано 12 грудня 2002 р., в остаточному вигляді - 8 квітня 2003 p.

Представлено результати ЕПР досліджень сегнетоелектричної кераміки $\mathrm{BaTiO}_{3}$ двох серій: легованої церієм та марганцем або ніобієм, стронцієм та марганцем, при кімнатній температурі. Показано, що у зразках першої серії найбільш інтенсивна лінія з $g$-Фактором 1.9612 належить до парамагнітного центру $\mathrm{Ti}^{3+}-\mathrm{Ce}^{3+}$. Лінії малої інтенсивності належать до центру $\mathrm{Fe}^{3+}-\mathrm{V}_{\mathrm{O}}$ (пов'язаного з неконтрольованою домішкою заліза у зразках) та до іону $\mathrm{Mn}^{2+}$.

В другій серії зразків спостерігався спектр, який відповідає надтонкій структурі іону $\mathrm{Mn}^{2+}$. Інтенсивність цього спектру зменшувалась із збільшенням концентрації стронцію. Можливо цей ефект пов'язаний із зменшенням розмірів зерен та міграцією марганцю та, можливо ніобію, у міжзерновий простір. Обговорюється вплив домішок, їх зарядового стану та позиції у кристалічній ґратці на ефект позитивного температурного коефіцієнту опору.

Ключові слова: кераміка $\mathrm{BaTiO}_{3}$, домішки, ЕПР, позисторний ефект

PACS: $72.80 . S k, 76.30 . F c, 77.84 . D y$ 